May Hawas, ed. The Routledge Companion to World Literature and World History

New York: Routledge, 2018. 350 p. ISBN: 9-781315-686271. £140

\title{
Stefan Helgesson
}

\section{(2) OpenEdition}

\section{Journals}

Electronic version

URL: https://journals.openedition.org/ces/441

DOI: $10.4000 /$ ces.441

ISSN: 2534-6695

\section{Publisher}

SEPC (Société d'études des pays du Commonwealth)

Printed version

Date of publication: 10 June 2019

Number of pages: $117-118$

ISSN: 2270-0633

\section{Electronic reference}

Stefan Helgesson, "May Hawas, ed. The Routledge Companion to World Literature and World History", Commonwealth Essays and Studies [Online], 41.2 | 2019, Online since 05 November 2019, connection on 17 July 2021. URL: http://journals.openedition.org/ces/441 ; DOI: https://doi.org/10.4000/ces.441

\section{(c) $\oplus \Theta \Theta$}

Commonwealth Essays and Studies is licensed under a Licence Creative Commons Attribution - Pas d'Utilisation Commerciale - Pas de Modification 4.0 International. 


\section{Reviews}

The Routledge Companion to World Literature and World History. Edited by May Hawas. New York: Routledge, 2018. 350 p. ISBN: 9-781315-686271. £140.

Reviewed by Stefan HeLgesson

World literature and world history can seem like a match made in heaven. In her own contribution to this impressively wide-ranging companion, the editor May Hawas makes two claims in support of such a view. The first is that world history offers an understanding of the "maturation of global networks over time" (219). The second is that world-historical crises can be posited as nodal points through which we can study literary production and reception. Her key example is the Suez Canal, a pre-eminent geopolitical pressure point across two centuries - but also with an ancient history as an idea and a dream before it was finally built. By first establishing a dense historical context in this way, Hawas can then bring Arabic, British, American, French and Indian literary texts to bear on her discussion. Her focus lies on the short century from the canal's opening in 1869 to the Suez crisis in 1956, which was as symbolic a marker of the new postcolonial era as the Bandung conference of 1955. Rudyard Kipling, Anthony Trollope, Langston Hughes, Rabindranath Tagore and others are in this way brought together under the aegis of an undeniably significant and conflictual historical site.

Hawas's chapter clearly aims at disrupting entrenched (national and/or linguistic) habits of thinking about literature and history, and can be read as exemplary of her own ambitions with the volume. It is also hard to disagree with the hope she expresses in the introduction for a "convergence" (XVII) of world literature and world history. Although companions and edited volumes of world literature are rife today, no other book on the market brings world history scholars so decisively into the conversation. At the same time, the volume also illustrates many of the conundrums that such an ambition must confront. Divided into three sections called "People," "Networks and Method," and "Transformations," the companion contains no less than 27 chapters, including two introductory surveys by the central scholars (in each respective field) David Damrosch and Patrick Manning. Just putting all of this together in one book is a tour de force, but it inevitably offers a kaleidoscopic, rather than neatly coherent, view of the issues at hand.

To engage with world literature is indeed to court paradox (I say this as a world literature scholar myself). If, on the one hand, critics want to give all literatures and languages their due, they gravitate, on the other, towards the dominant, hyper-central language of our time, English. Similarly, world literature is wedded both to "deep time" (prominent in this volume) and to the extremely contemporary (the "global novel"). And it can be both radically egalitarian ("minor literatures") and ludicrously hierarchical (the slim "canon" of world literature). Some of these discrepancies play themselves out also here if one considers, for example, the distance between Piero Boitani's astonishingly erudite historical survey pointedly called "Classics," and Amal Eqeiq's engaged and engaging essay on ethnography and recent Mexican/Mayan and Palestinian literature. 
World history seems not to be beleaguered by quite the same fractures, but Patrick Manning's claim that "world literature appears more fully developed as a field of theory and criticism than world history" (14) is intriguing. The flipside to this is his understated observation that world historians "may find themselves surprised by the breadth of generality of the propositions debated in world literature" (19). There we find, perhaps, a crucial difference in ethos between the disciplines of history and literature: at best, a productive contrast between empirical rigour and strong ideas.

But we must not be taken in by any illusion of parity between the two fields of knowledge. As Damrosch points out (8), history will always be the bigger fish in the pond. Although literary theory, in the heyday of the linguistic turn, could claim priority in the humanities (as evidenced by Hayden White's meta-history), contributions to this companion tend rather to defer to history, or implicitly argue that literature derives its value from providing a different form of historical knowledge - as in Nandini Dhar's superb reading of Amitav Ghosh's Sea of Poppies. This is not necessarily a matter of deferring to history as a discipline in the strict sense, but certainly to the historical dimension of literature, and to literature as history.

Extrapolating on the ethical and political consequences of such a manoeuvre, Bruce Robbins suggests that world literature has still not fully worked through the implications of its commitment to deep-time world-historical perspectives. If world literature offers a narrative of "modernity as decline" (197) by projecting the nation-state and national literature as its big Other, this calls the vector of democratisation as a political ideal into question. The long and short of his argument is that the neutrally descriptive approach to literature in history will ultimately need to declare its position vis-à-vis democratic ethics.

In terms of method, Dhar's and Robbins's chapters illustrate the extreme scalar points between which the contributions position themselves: Dhar close reads a single novel, Robbins roams the epochs and the planet in his discussion. One could describe this as a contrast between (literary) experience and external description or analysis. If one takes the multilingual, deep-historical and transcontinental purview of world literature seriously, as Hawas does with her companion, this necessarily entails an attenuation of literary experience. I delight here in learning about the great Azerbajani writer Nizāmī (1141-1209) in Michael Barry's account. Likewise, it is remarkable to catch a glimpse of Chinese-Vietnamese literary interactions in the fifteenth century in Liam C. Kelley's chapter. But hopelessly limited as my language skills are, I know that my experience of these texts will always be at least at one remove - if indeed I can be claimed to experience them at all. (A similar insight once prompted Franco Moretti to promote "distant reading" as the proper method for world literature.)

As though to offset the attenuation of experience, each of the three sections in the book begins with a chapter labelled "Artist in Action," where practitioners have their say: the writer/academic Tabish Khair, the writer/translator Maureen Freely, and the visual artist Shazia Shikander. These chapters serve as wise reminders of the force of aesthetic (and not just conceptual) practice, but they signal also the necessity not to impose closure on world literature or world history as fields of enquiry. It is the tensions and polarities themselves that constitute the fields, not any spurious one-size-fits-all methodology. 